\title{
Interaction of gelatin with stereospecific binding proteins and its enhancement of competitive binding assays
}

\author{
BEVERLEY E. PEARSON MURPHY1 AND MAVIS MARVIN
}

From the Endocrinology Laboratory, Queen Mary Veterans Hospital, and Department of Experimental Medicine, McGill University, Montreal, Canada

SYNOPSIS The effect of gelatin $(0.5 \mathrm{~g} / \mathrm{l})$ on binding curves at high dilution of three classes of stereospecific binding proteins was studied. These included two antibodies (to oestradiol and aldosterone), six transins (horse and dog transcortins, human thyroxine-binding globulin, human sex steroidbinding globulin, and guinea pig transprogestin), and one receptor (bovine adrenal protein kinase). Gelatin increased the apparent binding of all these proteins, particularly at the highest dilutions and sometimes in a striking manner. While much of this action can be attributed to its decreasing the adhesion of the dilute binding protein to glass, gelatin also increased the apparent uptake of some tracers by certain adsorbents. Similar findings were obtained using human gamma globulin $(2 \mathrm{~g} / \mathrm{l})$. These effects resulted in increased sensitivity and improved reproducibility in the assays employing them.

Although little is known about non-specific protein-protein interactions, it has been observed that the stability of one protein may be enhanced in the presence of another. For example, Leyendecker, et al noted the 'protection' of several binding proteins against the effects of solvent residues by the addition of large amounts of gamma globulin (Leyendecker, Wardlaw, and Nocke, 1972). Various proteins have been added to antibody solutions by many authors, including albumin and gelatin, for various reasons usually unstated, but without any documentation of their effects. Usually the aim is to prevent adhesion of the dilute proteins to glass by adding a second protein in high concentration to coat the glass surface.

Recently we have investigated the effect of gelatin on the binding curves of a number of proteins including antibodies, naturally occurring stereospecific plasma proteins (transins), and receptors. Gelatin enhanced the apparent binding at high dilutions of all those tested and in some cases markedly improved the sensitivity of the competitive binding assays employing them.

Gelatin is a protein obtained by boiling collagen (skin, tendons, ligaments, and bones) with water. It

\footnotetext{
${ }^{1}$ Associate, Medical Research Council of Canada.
}

Received for publication 23 May 1974. contains no tryptophane and very little tyrosine or cystine. In contact with water this protein swells and absorbs five to 10 times its own weight. Inexpensive (about 0.1 cent per gram), it has a great variety of commercial uses.

\section{Materials and Methods}

Gelatin (unflavoured, Knox Gelatin of Canada Ltd., Trenton, Ont. or G7, Laboratory grade, Fisher Scientific Co); human gamma globulin $16 \mathrm{~g} \%$ was obtained from Connaught Laboratories, Toronto, Ont.

Tritiated compounds were obtained from the New England Nuclear Co., nonradioactive ones from the Sigma Chemical Co. ${ }^{125}$ I-L-Thyroxine was obtained from the Frosst Co.

Adsorbents were obtained from the Fisher Scientific Co. Florisil (60/100 mesh) was washed with tap water or distilled water 50 times to remove the fines, then dried at $100^{\circ} \mathrm{C}$ until it no longer adhered to the plastic spoon used for dispensing. Alternatively, it was rinsed three times with ethanol and dried at room temperature. Forty $\mathrm{mg}$ was added to $1.0 \mathrm{ml}$ of solution.

The charcoal-dextran solution was made by suspending $250 \mathrm{mg}$ Norit $\mathrm{A}$ charcoal and $25 \mathrm{mg}$ dextran 
in buffer. One $\mathrm{ml}$ was added to $0.01 \mathrm{ml}$ of solution.

Resin (Rexyn $202\left(\mathrm{Cl}_{-} \mathrm{SO}_{4}\right)$ no. R-253) was rinsed several times with tap water, $\mathrm{NaOH}$, or ethanol to get rid of the fines and then dried at $100^{\circ} \mathrm{C}$ until it slipped easily from the plastic spoon for dispensing, when $0.5 \mathrm{~g}$ was added to $1.0 \mathrm{ml}$ of solution.

For counting tritium, $10 \mathrm{ml}$ of one of two solutions was used. Reagents were obtained from the New England Nuclear Co. For ${ }^{3} \mathrm{H}$-cyclic-AMP, a modified Bray's solution was made up as follows: to 1 US gallon of dioxane was added $400 \mathrm{~g}$ naphthalene, $28 \mathrm{~g}$ PPO (2, 5-diphenyl-oxazole), and $1.2 \mathrm{~g}$ dimethyl-POP (1, 4-bis-2-(4-methyl-5-phenoxyloxazolyl)-benzene). After shaking well, it was allowed to stand overnight before using. (Use a large bottle since it expands on standing.) For the tritiated steroids, $28 \mathrm{~g}$ of PPO was added to 1 gallon of toluene and shaken well. Ten $\mathrm{ml}$ was dispensed into each vial to which was added 1 drop of $4 \mathrm{~g} \%$ $\mathrm{SnCl}_{2}$ in $0 \cdot 1 \mathrm{~N} \mathrm{HCl}$. The samples were shaken thoroughly and allowed to stand for two hours before counting.

All studies were carried out in Kimax glass culture tubes $(100 \mathrm{~mm} \times 16 \mathrm{~mm}$, borosilicate glass, Kimble brand, Canlab no. T1320-8) unless otherwise stated. In some instances, polypropylene tubes (-2018, Falcon Plastics, 1950 Williams Drive, Oxford, Ca. 93030, USA) were used.

The general methodology employed was that described previously for corticosteroids (Murphy, 1967), androgens (Murphy, 1969), thyroxine (Murphy, 1965), and cyclic AMP (Tsang, Lehotay, and Murphy, 1972). The oestrogen immunoassay was based on that of Hotchkiss et al (Hotchkiss, Atkinson, and Knobil, 1971). Binding curves at protein concentrations close to those used for CPB assays were compared in the presence and absence of gelatin $500 \mathrm{mg} / \mathrm{l}$ or human $\gamma$-globulin, $2 \mathrm{~g} / \mathrm{l}$. Values shown are the means of duplicates. Curves plotted on the same graph were determined simultaneously.

\section{Results}

\section{ADHESION OF GELATIN TO GLASS AND \\ POLYPROPYLENE}

Gelatine $(0.3 \mathrm{mg})$ was radioiodinated with ${ }^{125}$ I using the chloramine-T procedure (Greenwood, Hunter, and Glover 1963) and purified both by Sephadex column chromatography and by exposure to resin, which adsorbs free iodine. The purified gelatin was then diluted with phosphate buffer $(\mathrm{pH} \mathrm{7.4,0.075}$ M). Aliquots were pipetted into tubes, agitated gently, at $4^{\circ} \mathrm{C}$ for one hour, and the supernatants transferred for counting. The results are shown in table I. It was found that, expressed as a percentage, adhesion to glass was negligible at $1 \mathrm{mg} / \mathrm{ml}$ but increased significantly on dilution to $0.1 \mathrm{mg} / \mathrm{ml}$ and below. Adhesion to polypropylene was significant even at the $1 \mathrm{mg} / \mathrm{ml}$

\begin{tabular}{lll}
\hline & \multicolumn{2}{l}{ Adhesion $(\%)^{1}$} \\
\cline { 2 - 3 } $\begin{array}{l}\text { Gelatin Concentration } \\
(m g / m l)\end{array}$ & Glass & Polypropylene \\
\hline 1.0 & & \\
0.1 & $0.01 \pm 0.002$ & $2.5 \pm 1.0$ \\
0.01 & $5.0 \pm 1.7$ & $11.5 \pm 1.5$ \\
& $7.3 \pm 1.0$ & $26.6 \pm 1.8$ \\
\hline
\end{tabular}

Table I Adhesion of gelatin to test tubes

${ }^{1}$ Mean $\pm S E ; n=6 ;$ after gentle agitation for one hour at $4^{\circ} \mathrm{C}$

\begin{tabular}{|c|c|c|c|c|c|}
\hline \multirow[b]{2}{*}{ Tracer } & \multirow[b]{2}{*}{ Adsorbent } & & \multirow[b]{2}{*}{ Medium } & \multicolumn{2}{|c|}{ Apparent Percentage Bound ${ }^{1}$} \\
\hline & & & & Gelatin Absent & Gelatin Present \\
\hline \multirow[t]{3}{*}{${ }^{8} \mathrm{H}$-corticosterone } & Unwashed & Florisil & Water & $36 \cdot 0$ & $12 \cdot 4^{2}$ \\
\hline & Water-washed & Florisil & & $8 \cdot 2$ & $5 \cdot 7^{2}$ \\
\hline & Alcohol-washed & Florisil & & $4 \cdot 9$ & $5 \cdot 2$ \\
\hline \multirow[t]{3}{*}{ 'H-progesterone } & Unwashed & Florisil & Water & $32 \cdot 2$ & $14 \cdot 7^{2}$ \\
\hline & Water-washed & Florisil & & $11 \cdot 8$ & $4 \cdot 2^{2}$ \\
\hline & Alcohol-washed & Florisil & & 6.9 & $2 \cdot 9^{2}$ \\
\hline \multirow[t]{3}{*}{${ }^{\mathbf{3}} \mathbf{H}$-cyclic AMP } & Water-washed & Resin & $6.7 \mathrm{mM}$ Tris pH 7.7 & $10 \cdot 2$ & $11 \cdot 2$ \\
\hline & Alkali-washed & Resin & $0.45 \mathrm{mM}$ EDTA & $14 \cdot 6$ & 14.6 \\
\hline & Alcohol-washed & Resin & $1 \mathrm{mM}$ theophylline & $13 \cdot 4$ & $14 \cdot 3$ \\
\hline \multirow[t]{3}{*}{ I $^{125}$-thyroxine } & Water-washed & Resin & Barbital buffer $0.075 \mathrm{M}$ pH 8.6 & $5 \cdot 7$ & $6 \cdot 2$ \\
\hline & Alkali-washed & Resin & & $4 \cdot 7$ & $6 \cdot 2$ \\
\hline & Alcohol-washed & Resin & & 6.8 & $7 \cdot 5$ \\
\hline${ }^{\mathbf{3}} \mathrm{H}$-testosterone & Charcoal & Dextran & Phosphate buffer $0.2 \mathrm{M}$ pH 6.0 & $4 \cdot 2$ & $3 \cdot 3$ \\
\hline \multirow[t]{3}{*}{${ }^{3} \mathrm{H}$-aldosterone } & Unwashed & Florisil & Water & $17 \cdot 5$ & $9 \cdot 0^{2}$ \\
\hline & Water-washed & Florisil & & $7 \cdot 8$ & $8 \cdot 5$ \\
\hline & Alcohol-washed & Florisil & & $5 \cdot 3$ & 6.9 \\
\hline${ }^{8} \mathrm{H}$-oestradiol & Charcoal & Dextran & Buffer & $3 \cdot 6$ & $1 \cdot 6^{2}$ \\
\hline
\end{tabular}

Table II Effect of gelatin on the binding of tracer in the absence of stereospecific binding proteins

${ }^{1}$ Each value is the mean of at least four determinations.

'Difference from control with gelatin absent $(P<0.05)$. 
level. Iodinated albumin and iodinated parathormone also adhered to a greater extent to polypropylene. The addition of unlabelled gelatin $0.5 \mathrm{mg} / \mathrm{ml}$ to low concentrations of parathormone decreased the adhesion to glass to a negligible extent. Sinceplasma contains about $70 \mathrm{mg} / \mathrm{ml}$ protein, significant effects can therefore be expected at dilutions approaching $1: 100$.

THE EFFECT OF GELATIN ON THE UPTAKE OF TRACERS BY ADSORBENTS

To determine whether gelatin might bind some of the tracers itself, the uptake of tracer by each adsorbent was studied in water or buffer in the presence and absence of gelatin (table II). Uptake of ${ }^{3} \mathrm{H}$-corticosterone and ${ }^{3} \mathrm{H}$-progesterone by Florisil were, unexpectedly, increased by gelatin, particularly if the Florisil was not washed. Highest uptake was obtained by alcohol washing of the Florisil and after this procedure the gelatin made little difference.

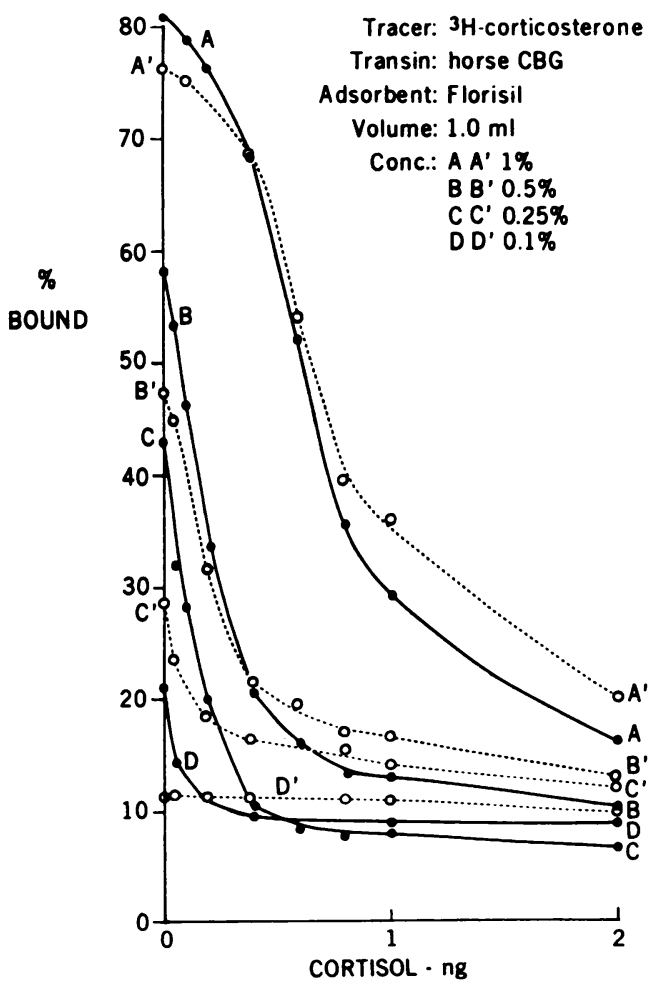

Fig 1 Binding curve of cortisol to horse serum diluted in water to the concentration and final volume indicated. Water-washed Florisil was used. A, B, C, D: gelatin added. $A^{\prime}, B^{\prime}, C^{\prime}, D^{\prime}$ : no gelatin added.
THE EFFECTS OF GELATIN ON THE BINDING OF TRANSINS

These are shown in figures 1-5. The competition of cortisol for the binding of ${ }^{3} \mathrm{H}$-corticosterone to the corticosteroid-binding globulin (CBG) in horse serum is shown in figure 1 . At a dilution of $1 \%$ with water the typical changes observed were increased initial binding and decreased final binding. These effects became more pronounced at higher dilutions $(0.5 \%$ and $0.25 \%)$ until at $0.1 \%$ a curve was still obtained for the range 0 to $300 \mathrm{pg}$ cortisol in the presence of gelatin while only a flat line was observed in its absence. Similar though less dramatic changes were observed for similar experiments using dog serum (fig 2). Large changes occurred in the binding of ${ }^{3} \mathrm{H}$-progesterone to pregnant guinea-pig serum as shown in figure 3. Substantial increases in binding occurred in the presence of gelatin, permitting a very satisfactory assay for progesterone at a dilution of $1: 10000$ whereas even at $1: 3000$ very poor reproducibility was achieved in its absence. Similarly, the binding of ${ }^{3} \mathrm{H}$-testosterone to late pregnancy human plasma gave an excellent assay curve for the range 0 to $200 \mathrm{pg}$ dihydrotestosterone (fig 4) in the presence of gelatin and a less satisfactory one in its absence. The day-to-day reproducibility of the results was also enhanced by gelatin. The binding of 1-thyroxine to human serum showed similar but less marked changes (fig 5).

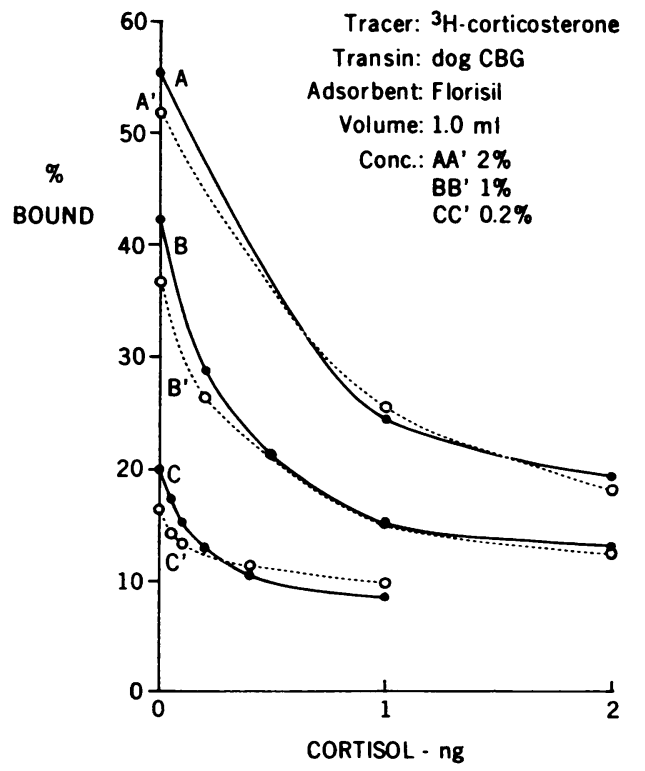

Fig 2 Binding curve of cortisol to dog serum diluted in water. Water-washed Florisil was used. Captions as in figure 1. 


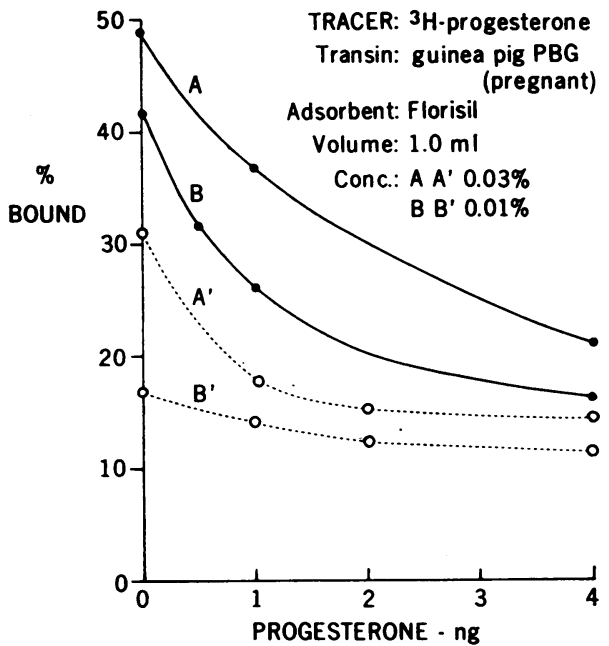

Fig 3 Binding curve of progesterone to guinea-pig serum (late pregnancy) diluted in phosphate buffer. Water-washed Florisil was used. Captions as in figure 1.

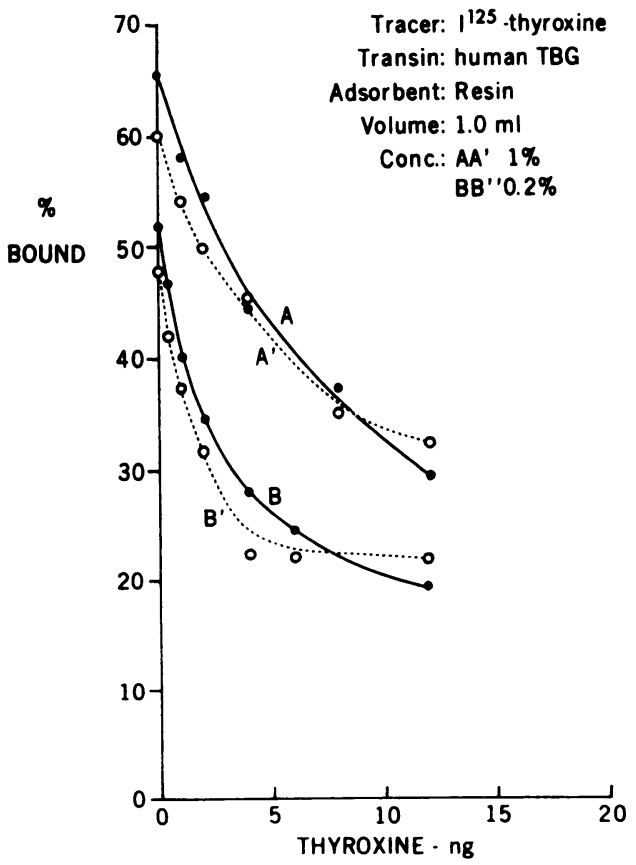

Fig 5 Binding curve of 1-thyroxine to human serum diluted with barbital buffer. Water-washed resin was used. Captions as in figure 1.

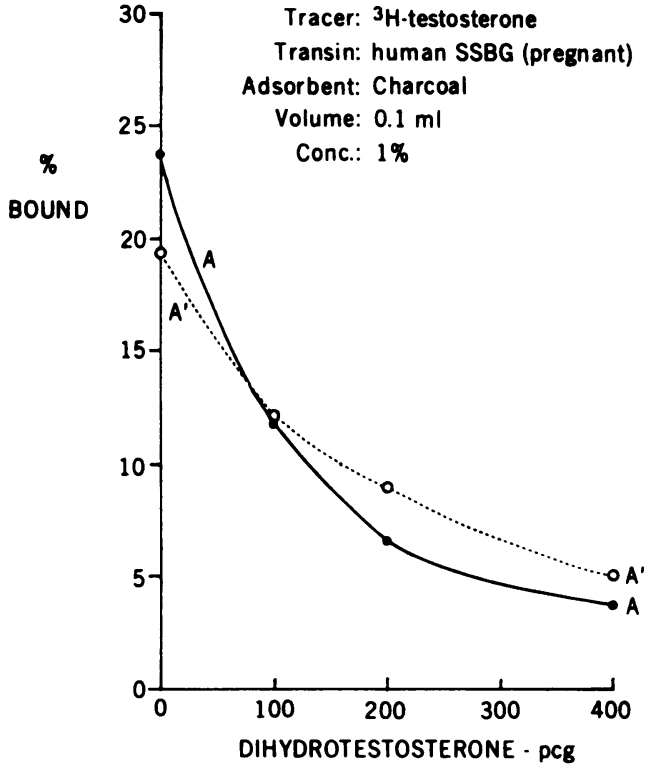

Fig 4 Binding curve of dihydrotestosterone to human serum (late pregnancy) diluted in phosphate buffer using charcoal as adsorbent. Captions as in figure 1.

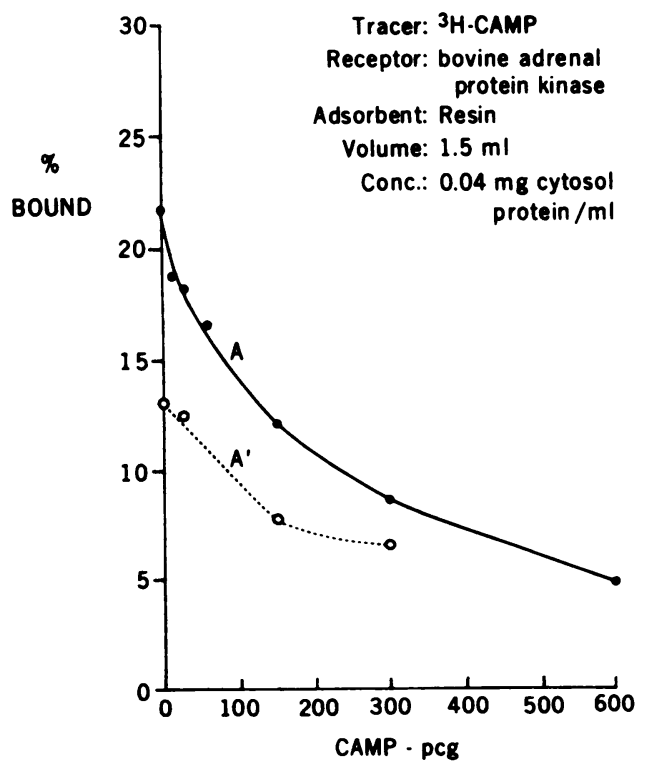

Fig 6 Binding curve of cyclic AMP to bovine adrenal cytosol. Alkali-washed resin was used. Captions as in figure 1. 


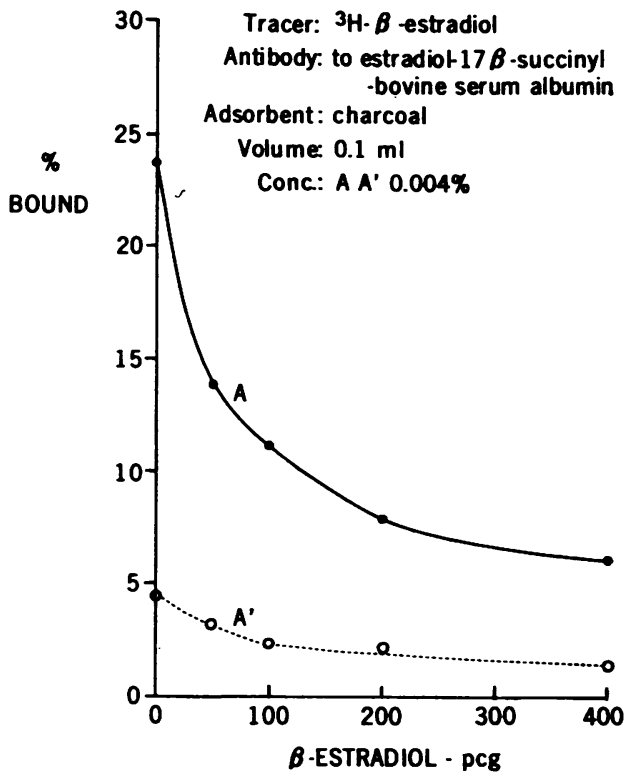

Fig 7 Binding curve of oestradiol to oestradiol antiserum diluted in phosphate buffer using charcoal. Captions as in figure 1 .

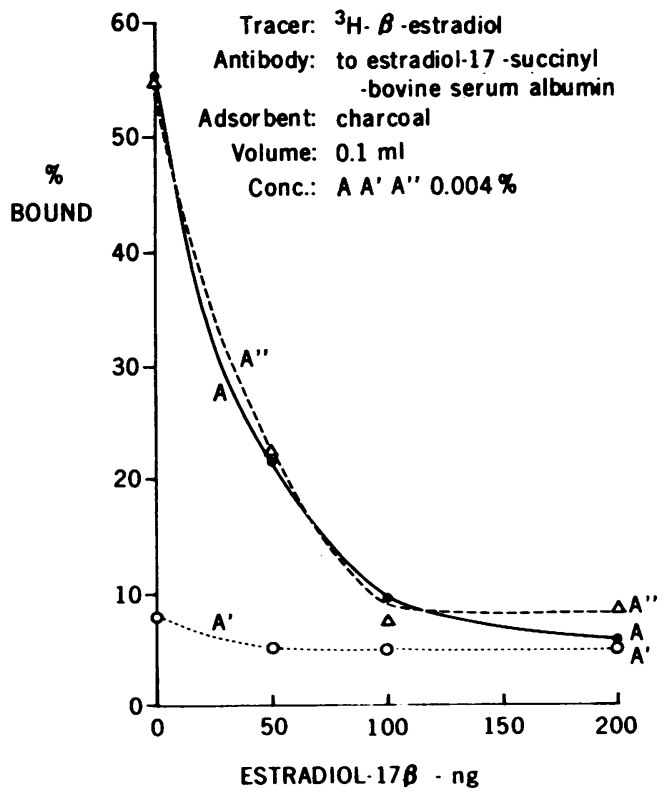

Fig 9 Binding curve of oestradiol using oestradiol antiserum diluted with buffer and using charcoal as adsorbent. $A^{\prime}:$ no other protein added. A: gelatin added. A": human gamma globulin added.

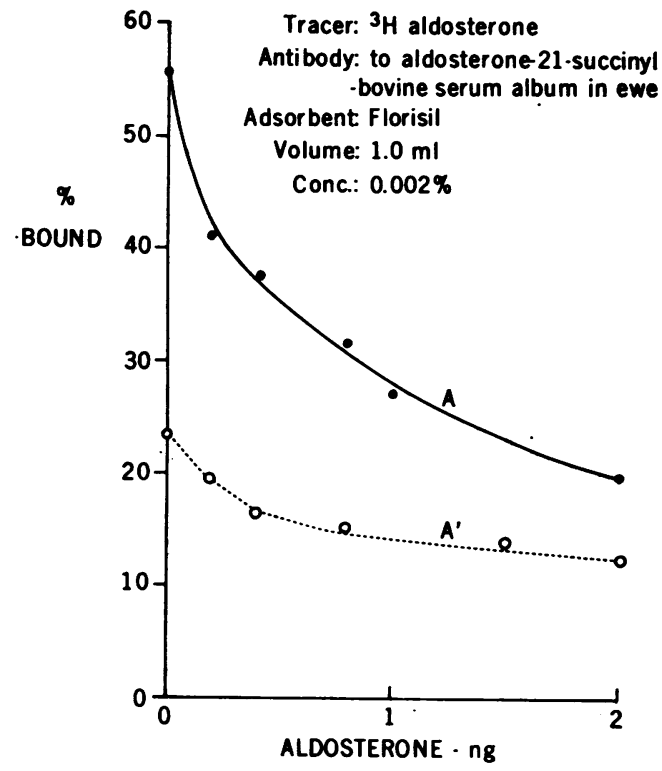

Fig 8 Binding curve of aldosterone to aldosterone antiserum diluted in water. Water-washed Florisil was used. Captions as in figure 1.

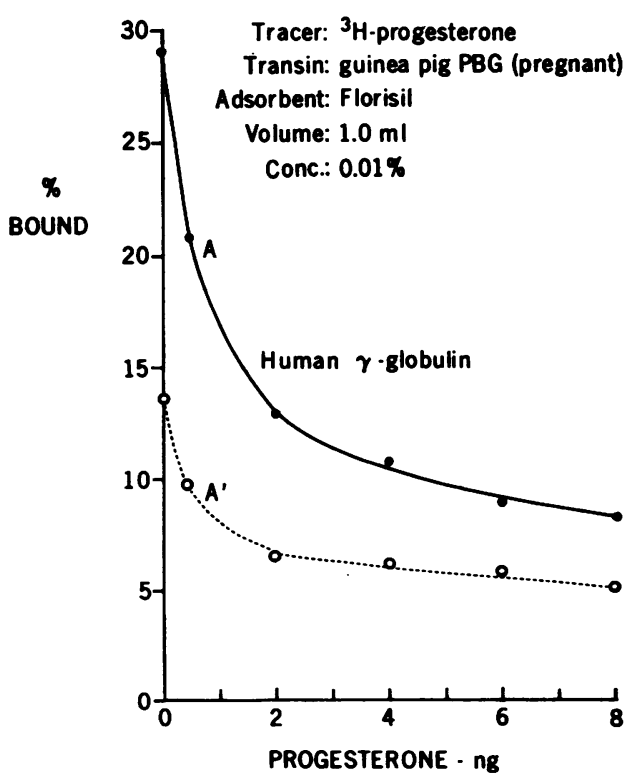

Fig 10 Binding curve of progesterone to guinea-pig serum (late pregnancy) diluted in water. Alcohol-washed Florisil was used. $A^{\prime}$ : no other protein added. A: human gamma globulin added. 


\begin{tabular}{|c|c|c|c|}
\hline Substance Measured & Protein & Without Gelatin & With Gelatin \\
\hline $\begin{array}{l}\text { Cortisol } \\
\text { Cortisol } \\
\text { Progesterone } \\
\text { Dihydrotestosterone } \\
\text { Testosterone } \\
\text { 1-Thyroxine } \\
\text { Cyclic AMP } \\
\text { Oestradiol } \\
\text { Aldosterone }\end{array}$ & $\begin{array}{l}\text { Horse CBG } \\
\text { Dog CBG } \\
\text { Guinea pig PBG } \\
\text { Human SHBG } \\
\text { Human SHBG } \\
\text { Human TBG } \\
\text { Bovine adrenal cytosol } \\
\text { Oestradiol antiserum } \\
\text { Aldosterone antiserum }\end{array}$ & $\begin{array}{c}60 \mathrm{pg} \\
60 \mathrm{pg} \\
1 \mathrm{ng} \\
30 \mathrm{pg} \\
150 \mathrm{pg} \\
0 \cdot 3 \mathrm{ng} \\
70 \mathrm{pg} \\
>100 \mathrm{pg} \\
>200 \mathrm{pg}\end{array}$ & $\begin{array}{l}25 \mathrm{pg} \\
50 \mathrm{pg} \\
0 \cdot 14 \mathrm{ng} \\
10 \mathrm{pg} \\
60 \mathrm{pg} \\
0 \cdot 2 \mathrm{ng} \\
23 \mathrm{pg} \\
5 \mathrm{pg} \\
50 \mathrm{pg}\end{array}$ \\
\hline
\end{tabular}

Table III Sensitivity of competitive protein-binding assays

ANALOgOUS STUdies WiTH A RECEPTOR

Analogous studies were carried out with a receptor protein. The binding of ${ }^{3} \mathrm{H}$-cyclic AMP to the protein kinase of bovine adrenal showed enhancement of the initial binding (fig 6) permitting a more sensitive assay to be achieved than that originally described (Tsang, Lehotay, and Murphy, 1972).

\section{ANTIBODIES TO OESTRADIOL AND}

\section{ALDOSTERONE CONJUGATES}

Antibodies to an oestradiol and an aldosterone conjugate were studied in the same fashion. At an antibody concentration of $1: 25000$ binding of ${ }^{3} \mathrm{H}$-oestradiol was negligible in the absence of gelatin but satisfactory in its presence (fig 7). Similarly, the binding of ${ }^{3} \mathrm{H}$-aldosterone to the antibody to aldosterone-21-succinyl-bovine serum albumin at a dilution of 1:50 000 in water was greatly enhanced by gelatin (fig 8).

To determine whether the effectiveness of gelatin was due simply to increase in total protein concentration rather than to the gelatin itself, several of the experiments were repeated using human gamma globulin $2 \mathrm{~g} / \mathrm{l}$ in place of gelatin. Both the oestrogenantibody curve (fig 9) and the progesterone-transin curve (fig 10) were improved to an extent similar to that with gelatin.

Table III indicates the improvement in sensitivity achieved by using gelatin in the various assays. Sensitivity was estimated as $2 \mathrm{~S} / \mathrm{n}$ where $\mathrm{s}=$ standard deviation of values at or close to zero and $n$ is the number of replicate determinations, ie, two.

\section{Discussion}

These studies suggest that the interaction of gelatin with dilute proteins is a general phenomenon whereby the stability in solution of the dilute pro- teins is increased. The results using gamma globulin suggest that this type of interaction is not confined to gelatin but that proteins are more stable in concentrated protein solutions regardless of their protein composition. While the usefulness of adding other proteins to dilute antibody solutions has been frequently recognized in immunoassay work the authors were unable to find any documentation of their effects. Other proteins have not generally been added in radiotransin assays.

While it enhanced apparent binding by other proteins at high dilution gelatin itself appeared not to bind most small molecules significantly. It promoted uptake of small molecules by adsorbents, in some instances possibly by promoting aggregation of adsorbent particles and thus speeding up their settling. These properties, in addition to its cheapness and ready availability, make it a useful additive in many competitive binding assays.

\section{References}

Greenwood, F. C., Hunter, W. M., and Glover, J. S. (1963.) The preparation of ${ }^{131} \mathrm{I}$-labelled human growth hormone of high specific radioactivity. Biochem. J., 89, 114-123.

Hotchkiss, J., Atkinson, L. E., and Knobil, E. (1971). Time course of serum oestrogen and luteinizing hormone (LH) concentrations during the menstrual cycle of the Rhesus monkey. Endocrinology, 89, 177-1183.

Leyendecker, G., Wardlaw, S., and Nocke, W. (1972). Gamma globulin protection of radioimmunoassay and competitive protein binding saturation analysis of steroids. $J$. clin. Endocr., 34, 430-433.

Murphy, B. E. P. (1965). The determination of thyroxine by competitive protein-binding analysis employing an anion-exchange resin radiothyroxine. J. Lab. clin. Med., 66, 161-167.

Murphy, B. E. P. (1967). Some studies of the protein-binding of steroids and their application to the routine micro and ultramicro measurement of various steroids in body fluids by competitive protein-binding radioassay. J. clin. Endocr., 27, 973 990.

Murphy, B. E. P. (1969). Protein binding and the assay of nonantigenic hormones. Rec. Progr. Horm. Res., 25, 563-610.

Tsang, C. P. W., Lehotay, D. C., and Murphy, B. E. P. (1972). Competitive binding assay for adenosine $3^{\prime}, 5^{\prime}$-monophosphate employing a bovine adrenal protein: application to urine, plasma and tissues. J. clin. endocr. Metab., 35, 809-817. 